\title{
Immobilization of halophilic Aspergillus awamori EM66 exochitinase on grafted k-carrageenan-alginate beads
}

\author{
Mona A. Esawy ${ }^{1}$ - Ghada E. A. Awad ${ }^{1}$ - Walaa A. Abdel Wahab ${ }^{1}$. \\ Magdy M. M. Elnashar ${ }^{3,4}$ - Ahmed El-Diwany ${ }^{1}$ Saadia M. H. Easa ${ }^{2}$. \\ Fawkia M. El-beih ${ }^{2}$
}

Received: 2 December 2014/ Accepted: 23 June 2015/Published online: 11 January 2016

(c) The Author(s) 2016. This article is published with open access at Springerlink.com

\begin{abstract}
A novel extreme halophilic exochitinase enzyme was produced by honey isolate Aspergillus awamori EM66. The enzyme was immobilized successfully on k-carrageenan-alginate gel carrier (CA) with $93 \%$ immobilization yield. The immobilization process significantly improved the enzyme specific activity 2.6-fold compared to the free form. The significant factors influencing the immobilization process such as enzyme protein concentration and loading time were studied. Distinguishable characteristics of optimum $\mathrm{pH}$ and temperature, stability at different temperatures and $\mathrm{NaCl}$ tolerance for free and immobilized enzyme were studied. The immobilization process improved optimum temperature from 35 to $45^{\circ} \mathrm{C}$. The immobilized enzyme retained $76.70 \%$ of its activity after $2 \mathrm{~h}$ at $75{ }^{\circ} \mathrm{C}$ compared to complete loss of activity for the free enzyme. The reusability test proved the durability of the CA gel beads for 28 cycles without losing its activity.
\end{abstract}

Keywords Exochitinase $\cdot$ Honey isolate $\cdot$ Aspergillus awamori $\cdot$ Immobilization

Ghada E. A. Awad

ghadaawad18@yahoo.com

1 Department of Chemistry of Microbial and Natural Products, National Research Centre, Tahrir Street, Dokki, Cairo, Egypt

2 Department of Microbiology, Faculty of Science, Ain Shams University, Khalifa El-Maamon St., Cairo, Egypt

3 Centre of Scientific Excellence-Group of Encapsulation and Nanobiotechnology, Polymers Department, National Research Center, El-Behooth St., Dokki, Cairo, Egypt

4 Biomedical Science Department, Health Science School, Curtin University, Bentley, WA 6102, Australia

\section{Introduction}

Osmophilic microorganisms survive environmental extremes of desiccation, pressure and acidity; so it is expected that their bio-products will have some unique properties to adapt to such extreme conditions. In recent years, significant progress has been made in discovering and developing novel isolates from honey since it contained a great variety of dominant spores which are expected to have unique feature (Esawy et al. 2011, 2013). This expectation comes from the osmophilic nature of honey and its constituents which are mainly fructose (about $38.5 \%$ ) and glucose (about $31.0 \%$ ), Crosby (2004).

Chitinases can be divided into two major categories endochitinases and exochitinases (Graham and Sticklen 1994). Exochitinases can be divided into two subcategories: exochitinases and $\beta-1,4 N$-acetyl glucosaminidases. Exochitinases (EC 3.2.1.29), the objective of this study, catalyze the progressive release of diacetylchitobiose starting at the non-reducing end of chitin chains (Chuan 2006).

Several chitinolytic enzymes have been identified in various fungi including, Trichoderma harzian (El-Katatny et al. 2000; Sandhya et al. 2004) Trichoderma longibrachiatum IMI 92027 (Kovacs et al. 2004) Aspergillus niger LOCK 62 (Brzezinska and Jankiewicz 2012) and Aspergillus terreus (Ghanem et al. 2010).

Chitinolytic enzymes have been widely used in various processes including agricultural, biological and environmental fields (Graham and Sticklen 1994). Chitinases have received attention due to their use as a biocontrol agent (Mathivanan et al.1998) and developing transgenic plants (Wang et al. 2008).

Halophilic enzymes, known as extremozymes produced by halophilic microorganisms, have identical enzymatic 
features like their non-halophilic counterpart, but they exhibit different properties mainly in structure. Among these, two main points could be mentioned, (a) a high content in acidic amino acids located predominantly at the protein surface and (b) requirement for high salt concentration for better biological functions. The halophilic chitinases are quite important in view of the accumulation of a huge amount of chitin, the second most abundant renewable biomass after cellulose, particularly as arthropod integuments in marine environments (Elnashar et al. 2009).

Chitinase immobilization is necessary for hydrolysis of oligosaccharides and the reusability of the enzyme. Searching for carriers suitable for enzyme immobilization with high efficiency, could be easily used in industries and relatively low cost is always the aim of many recent studies. The immobilization technique would enable the reusability of enzymes for tens of times. In addition, it reduces the enzyme cost significantly (Elnashar et al. 2009). There are many techniques to immobilize enzymes, such as adsorption, covalent, encapsulation, entrapment, and cross linking (Salman et al. 2008). Each technique has its pros and cons; however, covalent technique has the advantage of keeping the enzymes well bound to the carrier, avoiding enzyme diffusion, and this is why it is widely preferred on the industrial scale (Danial et al. 2010). Enzyme immobilization by covalent bonding to an insoluble polymer has the supposed advantage of irreversible binding of the enzyme to the support matrix (Trevan 1988).

Covalent bonds are stronger due to the constant sharing of electrons between atoms. Biopolymers, such as alginates, carrageenans, and chitosans, are commercially available, have diverse features, and are available at a reasonable cost, which could make them good candidates for immobilizing enzyme (Hugerth et al.1997). Recently, various micro carriers, have become available for enzyme immobilization (Wei et al. 2000; Jia et al. 2002; Lee et al. 2004; Sawicka et al. 2005). Typically, smaller particles provide a larger surface area for enzymes attachment and a shorter diffusion path for the substrates (Kim et al. 2005).

This investigation concerned with the A. awamori EM66 exochitinase immobilization onto $\mathrm{k}$-carrageenan-alginate gel beads (CA). The factors influencing the immobilization yield were studied. The properties of the free and immobilized enzyme were investigated. The results indicated that, the high activity, thermo-tolerant and high salt-tolerant exochitinase produced by A. awamori EM66 could be useful for application in diverse areas such as biotechnology and agro-industry.

\section{Materials and methods}

\section{Chemicals}

k-Carrageenan (Mr: 154,000; sulfate ester $\sim 25 \%$ ), alginic acid sodium salt from brown algae (CAS \# 9005-38-3), Chitin from crab shells and $p$-nitrophenyl- $\beta$-D- $N$-acetyl glucoseaminide (PNP- $\beta$-GlcNAc) were purchased from Fluka Biochemika Co. (USA). Polyethyleneimine (MW: 423), Cat \# 468533, was obtained from Aldrich. All other reagents were of the purest grade commercially available.

\section{Microorganism (isolation and identification)}

The fungal used throughout this work was previously isolated from mountain honey bee collecting nectar from desert flower. Honey samples are fresh non-treated ripe honey (directly collected in beehives). It was identified based on morphological characterization and 18S rRNA sequence analysis (data not published yet). It was designed as A. awamori EM66. Gene Bank database was achieved in BLASTN searches at the National Center for Biotechnology Information (NCBI) site (http://www.ncbi.nlm.nih. gov) and take an Accs. NO (ACC No. KF774180).

\section{Media}

\section{Maintenance medium}

The organism was maintained on the usual potato dextrose agar medium (PDA) preferable for fungal growth.

\section{Fermentation medium}

The optimized medium of exochitinase production contains $\%$ (glucose 0.4 ; soyabean 0.4 ; chitin 1.0 ; wheat flour 0.4 ; sodium nitrate 0.02 ; cobber sulfate anhydrous 0.001 ; magnesium sulfate 0.05 ; dipotassium hydrogen phosphate 0.2 ; ferric chloride 0.001 ; manganese sulfate 0.002 ; calcium chloride 0.05 ). The $\mathrm{pH}$ was adjusted to 8.0.

\section{Enzyme assay}

Exochitinase activity was determined according to the method of (Matsumoto et al. 2004) using the chromogenic substrate $p$-nitrophenyl- $\beta$-D- $N$-acetyl glucoseaminide (PNP- $\beta-G l c N A c)$ as a substrate. One unit of the enzyme activity was defined as the amount of enzyme releasing $1 \mu \mathrm{mol}$ of $p$-nitrophenol per minute under the specified assay conditions. 


\section{Protein content}

This was estimated by the method of (Lowry et al. 1951) using Folin-Ciocalteu phenol reagent (FCR) and extrapolated from the standard curve of bovine serum albumin.

\section{Partial purification}

The crude A. awamori EM66 exochitinase was fractionated using ethanol concentrations (30-80\%). The precipitate was obtained by centrifugation $\left(10,000 \times g, 15 \mathrm{~min}\right.$ at $\left.4{ }^{\circ} \mathrm{C}\right)$ and suspended in an appropriate volume of $0.05 \mathrm{M}$ acetate buffer ( $\mathrm{pH}$ 5.0).

\section{Immobilization}

The partially purified enzyme has been covalently immobilized onto alginate-carrageenan gel beads where half gram of gel beads was soaked for $24 \mathrm{~h}$.

Immobilization yield $=(I / A-B)(\%)$

$A$ is the enzyme added (mU/carrier), $B$ is the unbound enzyme (mU/carrier) and $I$ is the immobilized enzyme (mU/carrier).

\section{Preparation of grafted alginate-carrageenan beads}

One $\mathrm{g}$ of alginate and $1 \mathrm{~g}$ of $\mathrm{k}$-carrageenan were dissolved in distilled water to give a final concentration of $2 \%(\mathrm{w} / \mathrm{v})$ was dropped through $300 \mu \mathrm{m}$ nozzle in a hardening solution using the two-step method (Danial et al. 2010) the beads were treated by $2 \%(\mathrm{w} / \mathrm{v}) \mathrm{CaCl}_{2}\left(\mathrm{Ca}^{2+}\right)$ for $2 \mathrm{~h}$ then were dropped in a solution of $2 \%(\mathrm{w} / \mathrm{v}) \mathrm{CaCl}_{2}$ dissolved in $4 \%(\mathrm{v} / \mathrm{v})$ polyethylenimine at $\mathrm{pH} 8$ for $2 \mathrm{~h}$. The treated gels beads were then soaked in a solution of $2.5 \%(\mathrm{v} / \mathrm{v})$ glutaraldehyde (GA) for $2 \mathrm{~h}$ to incorporate the new functionality, aldehyde group. The solutions were mixed thoroughly using an overhead mechanical stirrer until complete dispersion had occurred. The gels were prepared into uniform beads using the Inotech Encapsulator (Elnashar et al. 2013).

Immobilization of exochitinase onto grafted $k$-carrageenan-alginate beads and soluble protein determination The k-carrageenan-alginate gel carrier (CA) was used to immobilize exochitinase by soaking $0.5 \mathrm{~g}$ of the gel beads in $2.5 \mathrm{~mL}$ of diluted enzyme contained $0.256 \mathrm{mg}$ protein (appropriate dilution was done) in $0.05 \mathrm{M}$ acetate buffer at $\mathrm{pH} 5.0$ for $24 \mathrm{~h}$. The beads were washed twice thoroughly for 30 min with acetate buffer to get rid of any unbound enzyme. The gel beads containing the immobilized enzyme were stored at $4{ }^{\circ} \mathrm{C}$ for further measurements. The supernatant and the wash were kept for soluble protein assay via bovine serum albumin (BSA) as a standard protein. Protein concentration of free enzyme was determined as described by (Lowry et al. 1951). The protein concentration of the immobilized enzyme was estimated by taking into consideration the protein concentration in the initial solution and of the unbound protein. The amount of protein immobilized onto and into the gel carrier $\mathrm{Pg}(\mathrm{mg} / \mathrm{g})$ was calculated using the following equation:

$\mathrm{Pg}=\frac{C_{\mathrm{o}} V_{\mathrm{o}}-C_{\mathrm{f}} V_{\mathrm{f}}}{W}$

where $C_{\mathrm{o}}$ is the initial protein concentration $(\mathrm{mg} / \mathrm{mL}), C_{\mathrm{f}}$ the protein concentration of the filtrate $(\mathrm{mg} / \mathrm{mL}), V_{\mathrm{o}}$ the initial volume of the enzyme solution $(\mathrm{mL}), V_{\mathrm{f}}$ the volume of filtrate $(\mathrm{mL})$, and $\mathrm{w}$ is the weight of gel carrier used $(\mathrm{g})$. The enzyme activity for immobilized enzyme was determined. An equal amount of enzyme $(0.5 \mathrm{ml}$ enzyme equivalent to $0.5 \mathrm{~g}$ gel of gel beads) and $0.5 \mathrm{ml}$ of $p$-nitrophenyl- $\beta-N$-acetyl glucosaminide as substrate were incubated for $1 \mathrm{~h}$ at $30{ }^{\circ} \mathrm{C}$. The reaction was stopped by addition of $25 \mathrm{ml}$ of $0.125 \mathrm{M}$ sodium borate buffer, $(\mathrm{pH}$ 10.1). The amount of released $p$-nitrophenol was measured at the absorbance $410 \mathrm{~nm}$ as mentioned previously.

\section{Effect of different incubation time on the activity of both partially purified and immobilized enzymes}

In this experiment, the assay was done for different time periods ranging from 2 to $120 \mathrm{~min}$ to investigate the optimal incubation time at which maximum enzyme activity occurred. Reaction mixture contain equal amount of substrate dissolved in sodium acetate buffer at $\mathrm{pH} 5.0$ and the enzyme as usual.

\section{Optimization of the immobilization yield (\%)}

\section{Optimization of loading time}

For determination of the optimum loading time, enzyme in suitable concentration was incubated with gel beads for different periods of time ranged from 2 to $24 \mathrm{~h}$. After loading time was finished, the gel beads were washed twice thoroughly for $30 \mathrm{~min}$ with acetate buffer to get rid of any unbound enzyme and the usual assay has been implicated.

\section{Optimization of the enzyme loading capacity}

In this experiment, $0.5 \mathrm{~g}$ of the gel beads was soaked in $2.5 \mathrm{~mL}$ of original enzyme solution in addition to the different enzyme dilutions $1: 2,1: 4,1: 6$, and $1: 8$ in $0.05 \mathrm{M}$ acetate buffer at $\mathrm{pH} 5.0$ for $18 \mathrm{~h}$. The gel beads were then washed twice thoroughly for $30 \mathrm{~min}$ with acetate buffer to 
get rid of any unbound enzyme and the usual assay has been implicated.

\section{Evaluation of exochitinase catalytic activity}

Different characters of A. awamori EM66 exochitinase for free and immobilized form, like effect of reaction conditions (temperature, $\mathrm{pH}$ and substrate concentration), thermal stability and $\mathrm{NaCl}$ concentrations have been tested.

\section{Operation temperature and $\mathrm{pH}$ profile}

The optimal temperature was determined by incubating the reaction mixture at different temperatures from 25 to $60{ }^{\circ} \mathrm{C}$. The optimal $\mathrm{pH}$ was investigated by measuring the activity between $\mathrm{pH} 4$ and 7 using sodium acetate buffer $(\mathrm{pH} 4-5)$ and sodium phosphate $(\mathrm{pH} \mathrm{5.5-7).}$

\section{Thermal stability}

Thermal stability has been achieved by incubating the partially purified and immobilized enzyme at different temperatures from $\left(35\right.$ to $\left.75^{\circ} \mathrm{C}\right)$ at different time periods (30, 60, 90 and $120 \mathrm{~min}$.). At the end of the incubation time, the usual enzyme assay has been carried out at the optimum conditions for each of the partially purified and immobilized enzyme.

$K_{m}$ and $V_{\text {max }}$ values of free and immobilized A. awamori exochitinase

The LineWeaver-Burk plot (double reciprocal) method, was used to obtain the Michaelis-Menten kinetic models adequate for the description of the hydrolysis of $p$-nitrophenyl- $\beta$ - $N$-acetyl glucosaminide by the free and the immobilized enzymes, apparent $K_{\mathrm{m}}$ and $V_{\max }$ of free and immobilized exochitinase. The assay mixture comprised 0.84 and $0.178 \mathrm{mg} / \mathrm{mL}$ of free and immobilized enzyme, a substrate concentration of $0.25-4.0 \mathrm{mg}$ at $\mathrm{pH} 5.0$, assay temperature was 30 and $45^{\circ} \mathrm{C}$ for free and immobilized enzymes, respectively.

\section{Effect of different $\mathrm{NaCl}$ concentrations}

One $\mathrm{ml}$ of enzyme contained 0.84 and $0.178 \mathrm{mg} / \mathrm{mL}$ of free and immobilized enzymes, respectively, was incubated with $1 \mathrm{ml}$ of $\mathrm{NaCl}$ to reach final concentration ranged from $(0.125$ to $6 \mathrm{M})$ in the absence of substrate for half an hour, after that the usual enzyme assay has been carried out at the optimum conditions for each of the partially purified and immobilized enzymes.

\section{Reusability of immobilized exochitinase}

Immobilized A. awamori EM66 exochitinase beads $0.5 \mathrm{~g}$ were incubated with $0.5 \mathrm{~mL}$ of $p$-nitrophenyl- $\beta-N$-acetyl glucosaminide as substrate for $10 \mathrm{~min}$ at $45^{\circ} \mathrm{C}$. The reaction was decanted and stopped by separating the gel beads from the substrate. Then they were washed with acetate buffer pH 5.0 and the first step was repeated to start a new reaction. The amount of released $p$-nitrophenol was measured at the absorbance $410 \mathrm{~nm}$ as mentioned previously.

\section{Storage stability}

Both the immobilized and free exochitinase enzymes were stored in distilled water at $4{ }^{\circ} \mathrm{C}$ for 6 months. The activity was measured every 2 weeks using 0.84 and $0.178 \mathrm{mg}$ of protein for free and immobilized enzyme, respectively.

\section{Statistical analysis}

Data analysis was carried out with MICROSOFT EXCEL (2007). All data are presented as mean \pm standard error of means. All results were independently replicated three times $(n=3)$, with three measurements per replicate. The mean of the repeated measurements yielded the value for each replicate.

\section{Results and discussion}

\section{Partial purification}

Microorganisms isolated from an extreme environment have harsh and challenging conditions expected to be characteristic by unique features. The osmophilic nature of honey recommended it to be a good source for dormant spores which have new properties (Esawy et al. 2013). Within this context, A. awamori EM66 which was previously isolated from mountain honey reported good exochitinase productivity. Under the optimized medium the enzyme productivity was $5998.91 \mathrm{mU} / \mathrm{mL}$. The crude enzyme was partially purified using ethanol fractionation (30-80 \%) v/v. Protein precipitated due to ethanol fractionation at $30 \% \mathrm{v} / \mathrm{v}$ showed about 18 times purification and recovered $22 \%$ of activity (in comparison to the overall activity of the culture supernatant). The partially purified enzyme was assayed for its total activity and protein content, which were found to be $23.34 \mathrm{U}$ and $0.837 \mathrm{mg}$, respectively. Accordingly, the specific activity was calculated to be $27.89 \mathrm{U} / \mathrm{mg}$. The high specific activity 
of this enzyme gave it tremendous interest; since it referred that it approaches to purity.

\section{Enzyme immobilization onto carrageenan-alginate gel beads (CA)}

The partially purified enzyme was immobilized by covalent binding with $93 \%$ immobilization yield (Table 1 ). The specific activity calculated on a bound-protein basis was $71.238 \mathrm{U} / \mathrm{mg}$. This result indicated that the immobilization process increased the specific activity 2.6-fold higher than that of free enzyme. In this finding, Riordan et al. (1989) reported that co-immobilization of Micromonospora chalcae with chitin in calcium alginate resulted in twofold increase in chitinase activity compared to the free form. On the other hand, it was found that the activity of immobilized chitinase in the rotational magnetic field rise compared to those in the absence of it (Mizuki et al. 2013). Finally, it was reported in active Serratia marcescens chitinase immobilized successfully by covalent binding to the polymer (hydroxypropyl methyl cellulose acetate succinate, AS-L) Chen and Chang (1994).

\section{Optimum incubation period}

Investigation of the convenient time for the maximum enzyme activity is important for getting the maximum substrate conversion in a short time. The optimum incubation time for both forms of A. awamori EM66 exochitinase had been recorded as 10 min (data not shown).

\section{Optimization of the immobilization yield}

In these experiments, the conditions to get the maximum enzyme loading capacity (ELC) and time were studied. The result was expressed as immobilization yield (\%). The immobilization yield increased proportionally with loading time reaching its maximum at $18 \mathrm{~h}$ incubation (97\%) (Fig. 1). The effect of different enzyme protein showed that A. awamori. EM66 exochitinase retained its complete enzyme activity at 1:2 dilutions; accordingly, the immobilization yield was $100 \%$ as shown in Fig. 2. It is worthy to know that the obtained immobilization yield (100\%) is higher than the yield obtained by (Sakai et al. 1991).

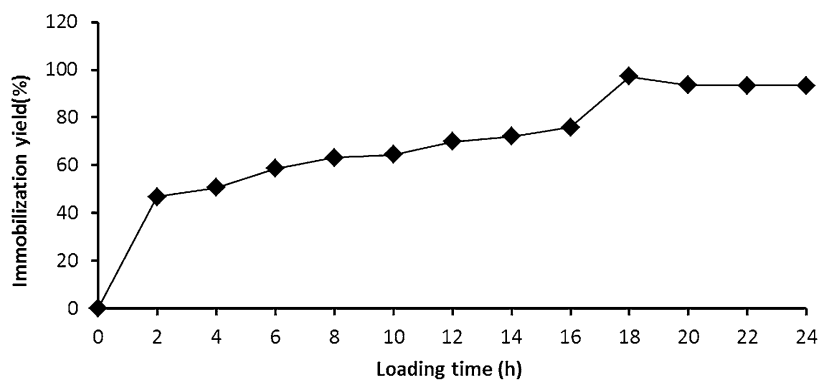

Fig. 1 Optimization of the enzyme loading time expressed in immobilization yield (\%) using grafted alginate/k-carrageenan prepared by covalent bond

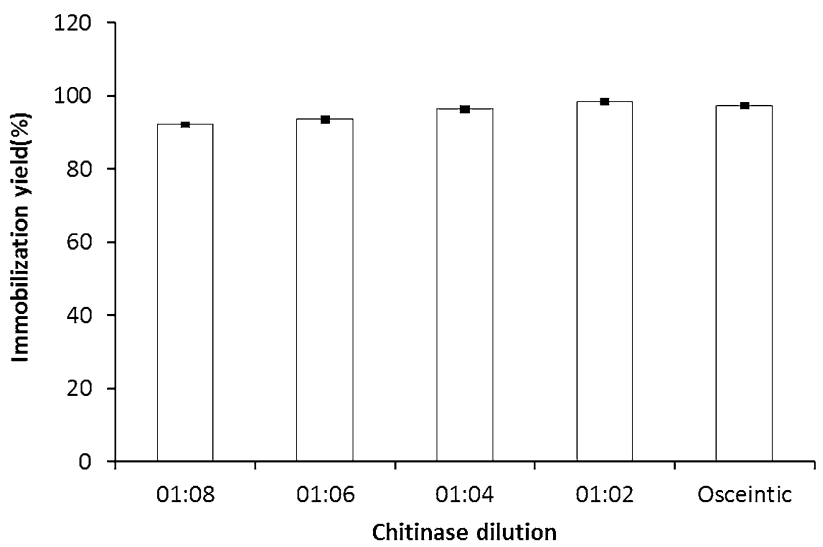

Fig. 2 Optimization of the enzyme loading capacity expressed in immobilization yield $(\%)$ using alginate/k-carrageenan beads prepared by covalent bond

\section{Temperature and $\mathrm{pH}$}

The optimal temperature was 35 and $45^{\circ} \mathrm{C}$ for free and immobilized enzyme, respectively (Fig. 3.). The shift of the enzyme's optimum temperature after immobilization could be regarded to the formation of a molecular cage around the protein (enzyme), which protected the enzyme's molecules from the bulk temperature (Roger et al. 2004). On contrary, Sakai et al. (1991) reported that the optimum temperature of the immobilized Nocardia orientalis IFO 12806 chitinase decreased from 60 to $40-50{ }^{\circ} \mathrm{C}$ in free and immobilized form, respectively. The optimum $\mathrm{pH}$ for both partially purified and immobilized enzyme was 5.0 using

Table 1 Immobilization of exochitinase using alginate/k-carrageenan carrier by covalent bond

\begin{tabular}{|c|c|c|c|c|}
\hline Carrier used & $\begin{array}{l}\text { Enzyme added } \\
\text { (mU/carrier) } \\
\text { (A) }\end{array}$ & $\begin{array}{l}\text { Unbound enzyme } \\
\text { (mU/carrier) } \\
\text { (B) }\end{array}$ & $\begin{array}{l}\text { Immobilized enzyme } \\
\text { (mU/carrier) } \\
\text { (I) }\end{array}$ & $\begin{array}{l}\text { Immobilization yield } \\
(\%) \\
(\mathrm{I} / \mathrm{A}-\mathrm{B})\end{array}$ \\
\hline $\begin{array}{l}\text { Alginate/k- } \\
\text { carrageenan }\end{array}$ & 2643.74 & 1327.801 & 1227.767 & $93.33 \pm 0.5$ \\
\hline
\end{tabular}




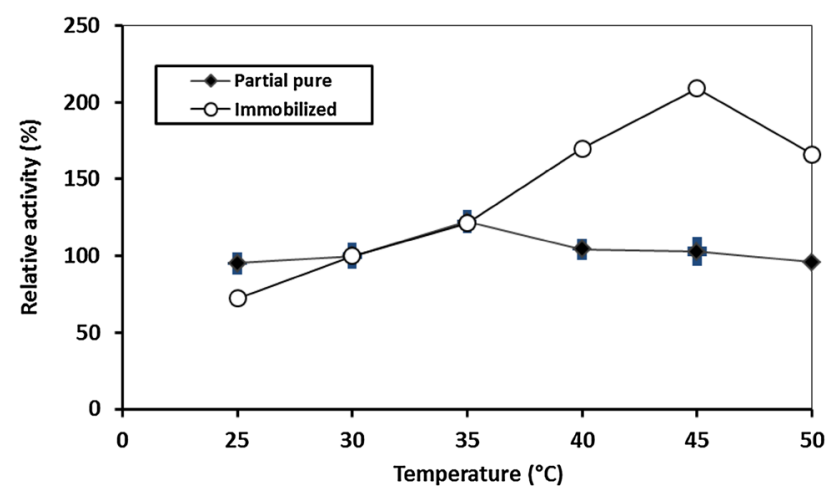

Fig. 3 Optimum temperature profile of free and immobilized $A$. awamori ESAWY exochitinase

acetate buffers $(0.05 \mathrm{M})$ (data not shown). In this finding, Wang and Chio (1998) reported in the immobilization of Pseudomonas aeruginosa K-187 chitinase where the optimum $\mathrm{pH}$ and temperature shifted to $\mathrm{pH} 8$ and $50{ }^{\circ} \mathrm{C}$.

\section{Thermal stability}

The thermal stability for the free and the immobilized enzyme was evaluated. The results referred to the complete loss of free enzyme activity at $\left(70\right.$ and $\left.75{ }^{\circ} \mathrm{C}\right)$ while the immobilized retained about $71 \%$ of its activity at $70{ }^{\circ} \mathrm{C}$ for $120 \mathrm{~min}$ and still active for about half activity at $75^{\circ} \mathrm{C}$ for $1 \mathrm{~h}$ (Fig. 4a, b). Prasad and Palanivelu (2013) found that the recombinant thermostable Thermomyces lanuginosus immobilized chitinase showed remarkable thermo stability at $50{ }^{\circ} \mathrm{C}$ by retaining about $45 \%$ of the activity for more than $6 \mathrm{~h}$. It was reported that the Bacillus thuringiensis chitinase had three times increase in the stability compared to the free form (Escudero-Abarca et al. 2002).

\section{$K_{\mathrm{m}}$ and $V_{\max }$ of free and immobilized exochitinase}

The kinetic constants of free and immobilized exochitinase were calculated using the double reciprocal plot method (Lineweaver-Burk plot) as shown in Fig. 5 Different reaction mixtures had been prepared with different substrate concentrations to determine the enzyme kinetics $\left(K_{\mathrm{m}}\right.$ and $\left.V_{\max }\right)$. Maximum activity occurred at 2.0 and $1.5 \mathrm{mg}$ concentration for partial pure and immobilized enzyme, respectively. $K_{\mathrm{m}}$ was calculated as 0.33 and $2.0 \mathrm{mg} / \mathrm{mL}$ and $V_{\max }$ as 13.33 and $40.0 \mathrm{U} / \mathrm{mg} / \mathrm{min}$ for free and immobilized form, respectively. The $K_{\mathrm{m}}$ value indicated that the partial pure enzyme is more sensitive to the substrate than the immobilized whereas the $V_{\max }$ value showed that the immobilized form is faster by about three times than the free form. It is worthy to mention that the kinetics of A. awamori. EM66 exochitinase differed from that of
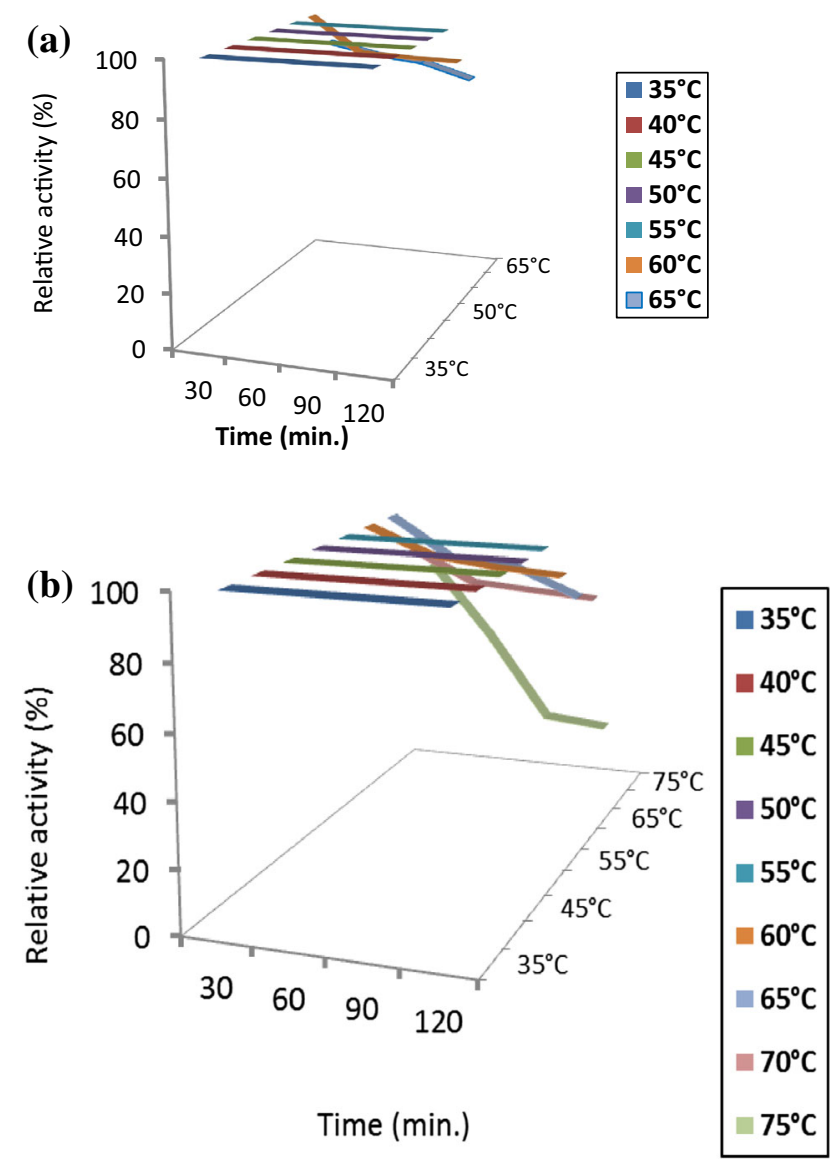

Fig. 4 Thermal stability profile of free (a) and immobilized (b) Aspergillus awamori ESAWY exochitinase

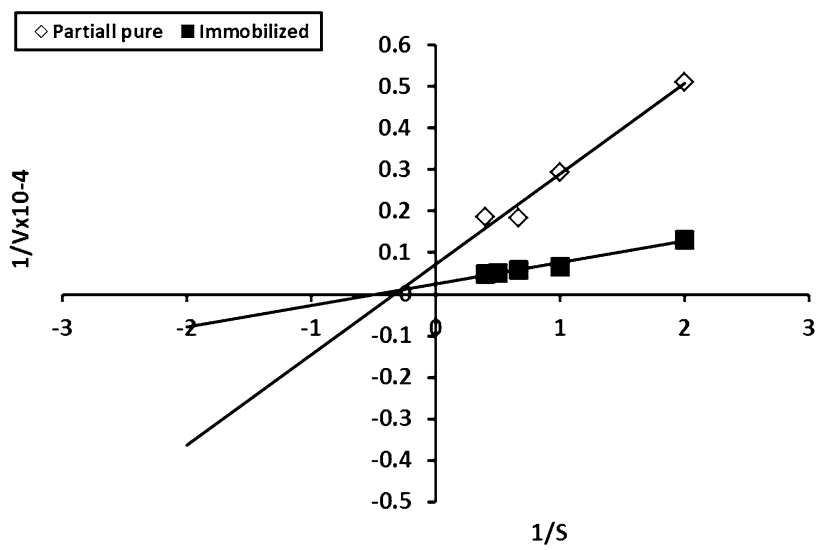

Fig. 5 Kinetic constants of free and immobilized A. awamori exochitinase using Lineweaver-Burk plot method

(Han et al. 2000) who recorded that acidic chitinases from the gizzards of a broiler had $K_{\mathrm{m}}$ and $V_{\max }$ of $0.42 \mathrm{mg} / \mathrm{mL}$ and $92.3 \mathrm{mg} / \mathrm{mg}$ protein $/ \mathrm{h}$, respectively, when the pentamer and hexamer of $\mathrm{N}$-acetylglucosamine (GlcNAc) were used as a substrate, Moreover, the $K_{\mathrm{m}}$ and $V_{\max }$ values 
for Serratia marcescens B4A chitinase were $8.3 \mathrm{mg} / \mathrm{mL}$ and $2.4 \mathrm{~m} \mathrm{~mol} / \mathrm{min}$, respectively, as reported by (Zarei et al. 2011).

\section{Effect of different $\mathrm{NaCl}$ concentrations}

The effect of different $\mathrm{NaCl}$ concentrations on the free and immobilized enzyme was achieved (Fig. 6). The highest relative activity (116 and $120 \%$ free and immobilized enzymes, respectively) was achieved at $0.75 \mathrm{M}$. In addition, both enzymes could tolerate the increase of $\mathrm{NaCl}$ concentrations to $6 \mathrm{M}$. This result could be attributed to the ability of honey microorganisms to adapt the honey osmophilic nature. Similar result was obtained from the honey isolate Bacillus subtilis NRC-B233b, where the dextranase activity increased about fourfold in the presence of $10 \% \mathrm{NaCl}$ (Esawy et al. 2012).

\section{Enzyme reusability}

One of the most important targets, of immobilization was the enzyme ability to be reused efficiently for several times. The reusability of immobilized A. awamori EM66 exochitinase has been studied because of its importance of repeated use in the batch or continuous processes. The results indicated to the great ability of the immobilized enzyme to keep its complete activity after 28 cycles (Fig. 7). In this finding, Wang, and Chio (1998) found that the immobilized Pseudomonas aeruginosa k-187 chitinase retained $70 \%$ of its original activity after 10 batches.

\section{Storage stability}

Enzyme stability issues are always of high significance in the production of stable and reproducible biocatalysts

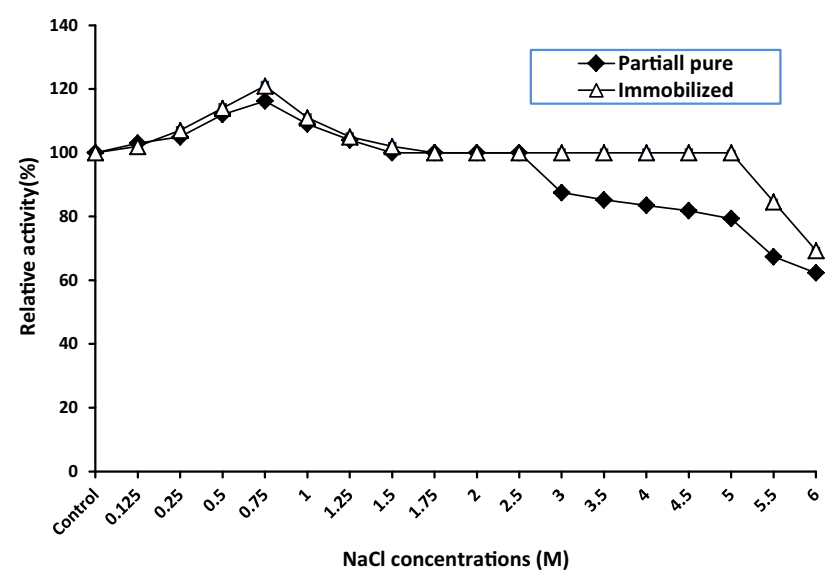

Fig. 6 Evaluation of different $\mathrm{NaCl}$ concentrations on free and immobilized Aspergillus awamori ESAWY exochitinase

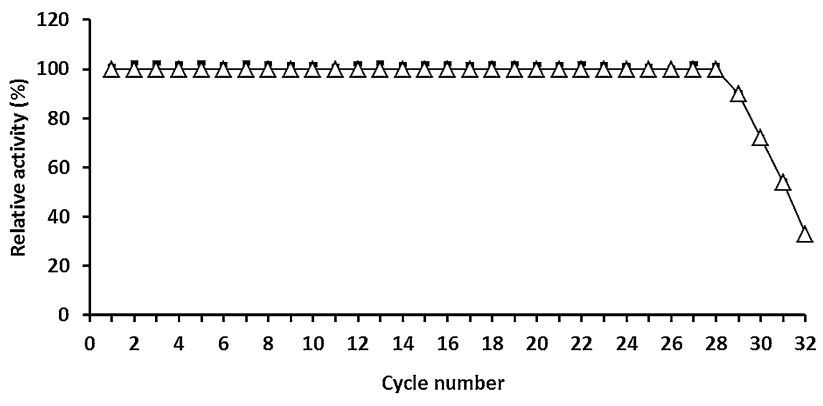

Fig. 7 Repeated cycle of immobilized Aspergillus awamori ESAWY exochitinase

(Danial et al. 2010). The storage stability is considered as an important parameter to confirm the enzyme stability. The results referred to the great stability of the free and immobilized form, both forms keep their complete stability at $4{ }^{\circ} \mathrm{C}$ for more than 6 months.

\section{Conclusion}

Till now there are no sufficient studies concerning exochitinase immobilization, accordingly our main purpose in this research aimed to characterize the free and immobilized enzyme from the novel honey isolate A. awamori EM66. In general, the immobilization process improved the enzyme properties such as temperature and thermal stability. In addition, the results referred to the thermostability character of both free and immobilized A. awamori EM66 chitinase, in addition to its unique halophilic property. The free enzyme showed good activity against Fusarium oxysporum which causes the plant wilt disease while the immobilized form lost this property. On the other hand, the immobilized form achieved great reusability. Thus, exochitinase produced by A. awamori EM66 could be useful for application in diverse areas such as biotechnology and agro-industry.

Acknowledgments This work supported by National Research Centre, Dokki, Giza, Egypt. We dedicate this work to the spirit of my dear sir Dr. Ahmed F. Abdel-Fattah, who planned this work.

\section{Compliance with ethical standards}

Conflict of interest None declared.

Open Access This article is distributed under the terms of the Creative Commons Attribution 4.0 International License (http:// creativecommons.org/licenses/by/4.0/), which permits unrestricted use, distribution, and reproduction in any medium, provided you give appropriate credit to the original author(s) and the source, provide a link to the Creative Commons license, and indicate if changes were made. 


\section{References}

Brzezinska MS, Jankiewicz U (2012) Production of antifungal chitinase by Aspergillus niger LOCK 62 and its potential role in the biological control. Curr Microbiol 65:666-672

Chen JP, Chang KC (1994) Immobilization of chitinase on a reversibly soluble-insoluble polymer for chitin hydrolysis. J Chem Technol Biotechnol 60:133-140

Chuan LD (2006) Review of fungal chitinases. Mycopathol. $161: 345-360$

Crosby AW (2004) Ecological imperialism: the biological expansion of Europe, 900-1900. Cambridge Univ. Press, pp 188. ISBN $0-521-54618-4$

Danial EN, Elnashar MMM, Awad GEA (2010) Immobilized inulinase on grafted alginate beads prepared by the one-step and the two-steps methods. Ind Eng Chem Res 49:3120-3125

El-Katatny MH, Somitsch W, Robra KH, El-Katatny MS, Gubitz GM (2000) Production of chitinase and $\beta$-1,3-glucanase by Trichoderma harzianum for control of the phytopathogenic fungus, Sclerotium rolfsii. Food Technol Biotechnol 38:173-180

Elnashar MMM, Danial EN, Awad GEA (2009) Novel carrier of grafted alginate for covalent immobilization of inulinase. Ind Eng Chem Res 48:9781-9785

Elnashar MM, Mostafa H, Morsy NA, Awad GEA (2013) Biocatalysts: isolation, identification and immobilization of thermally stable lipase onto novel supports. Ind Eng Chem Res 52:14760-14767

Esawy MA, Ahmed EF, Helmy WA, Mansour NM, El-Senousy WM, El-Safty MM (2011) Production of levansucrase from novel honey Bacillus subtilis isolates capable of producing antiviral levans. Carbohydr Polym 36:823-830

Esawy MA, Mansour SH, Ahmed EF, Hassanein NM, El Enshasy HA (2012) Characterization of extracellular dextranase from a novel halophilic Bacillus subtilis NRC-B233b a mutagenic honey isolate under solid state fermentation. Electron $\mathrm{J}$ Chem 9:1494-1510

Esawy MA, Hb Amer, Gamal-Eldeen AM, El Enshasy HA, Helmy WA, Abo-Zeid MAM, Malek R, Ahmed EF, Awad Ghada EA (2013) Scaling up, characterization of levan and its inhibitory role in carcinogenesis initiation stage. Carbohydr Polym 95:578-587

Escudero-Abarca BI, Sánchez-Ruiz B, Aguilar-Uscanga G, BarbozaCorona E, Cuneo M (2002) Immobilization of microbial chitinase on calcium alginate beads. In: Session 76A, Biotechnology, 8:30 AM-12:00 PM, 2002-06-18

Ghanem KM, Al-Garni SM, Al-Makishah NH (2010) Statistical optimization of cultural conditions for chitinase production from fish scales waste by Aspergillus terreus. Afr J Biotechnol 9:32

Graham LS, Sticklen MB (1994) Plant chitinases. Can J Bot 72:1057-1083

Han BK, Moon JK, Ryu YW, Park YH, Jo DH (2000) Purification and characterization of acidic chitinases from gizzards of broiler (Gallus gallus L.). J Biochem Mol Biol 33:326-331

Hugerth A, Caram-Lelham N, Sundeliir L (1997) The effect of charge density and conformation on the polyelectrolyte complex formation between carrageenan and chitosan. Carbohydr Polym 34:149-156

Jia HF, Zhu GY, Vugrinovich B, Kataphinan W, Reneker DH, Wang $\mathrm{P}$ (2002) Enzyme carrying polymeric nanofibers prepared via electrospinning for use as unique biocatalysts. Biotechnol Progr 18:1027-1032

Kim BC, Nair S, Kim J, Kwak JH, Grate JW, Kim SH, Gu MB (2005) Preparation of biocatalytic nanofibers with high activity and stability via enzyme aggregate coating on polymer nanofibers. Nanotechnol. 16:382-388

Kovacs K, Szakacs G, Pusztahelyi T, Pandey A (2004) Production of chitinolytic enzymes with Trichoderma longibrachiatum IMI 92027 in solid substrate fermentation. Appl Biochem Biotechnol 189:204

Roger S, Bee A, Balnois E, Bourmaud A, Le Deit, H, Ggohens Y, Cabuil V (2004) 15th International conference polymer-solvent complexes and intercalates, July 11-13, Lorient

Lee J, Han S, Hyeon T (2004) Synthesis of new nanoporous carbon materials using nano structured silica materials as templates. J Mater Sci 14:478-486

Lowry OH, Rosebrough NJ, Farr AL, Randall RJ (1951) Protein measurement with the Folin phenol reagent. J Biol Chem 193:265-275

Mathivanan N, Kamilan V, Murugesan K (1998) Purification, characterization and antifungal activity of chitinase from Fusarium chlamydosporum, a mycoparasite to groundnut rust, Puccinia arachidis. Can J Microbiol 44:646-651

Matsumoto Y, Castañeda GS, Revah S, Shirai K (2004) Production of $\beta$ - $N$-acetylhexosaminidase of Verticillum lecanii by solid state fermentation and submerged fermentation utilizing shrimp waste silage as substrate and inducer. Proc Biochem 39:655-671

Mizuki T, Sawai M, Nagaoka Y, Morimoto H, Maekawa T (2013) Activity of lipase and chitinase immobilized on superparamagnetic particles in a rotational magnetic field. PLoS One 8(6):e66528. doi:10.1371/journal.pone.0066528

Prasad M, Palanivelu P (2013) A novel method for immobilization of a thermostable fungal chitinase and the properties of the immobilized enzyme. Biotechnol Appl Biochem 61:441-445

Riordan AO, Mchale ML, Gallagher J, Mchale AP (1989) Chitinase production following co-immobilization of Microspora chalcae with chitin in calcium alginate. Biotechnol Lett 11:735-738

Sakai K, Matahira Y, Nanjo F (1991) Immobilization of chitinolytic enzymes and continuous production of $\mathrm{N}$-acetylglucosamine with the immobilized enzymes. J Ferment Bioeng 72:168-172

Salman S, Soundararajan S, Safina G, Satoh I, Danielsson BS (2008) Hydroxyapatite as a novel reversible in situ adsorption matrix for enzyme thermistor based FIA. Talanta 77:468-472

Sandhya C, Krishna LA, Nampoothri KM, Binod P, Szakacs G, Pandey A (2004) Extracellular chitinase production by Trichoderma harzianum in submerged fermentation. J Basic Microbiol 44:49-58

Sawicka KM, Prasad AK, Gouma PI (2005) Metal oxide nanowires for use in chemical sensing applications. Sens Lett 3:31-35

Trevan MD (1988) Enzyme immobilization by covalent bonding. Methods Mol Biol 3:495-510

Wang SL, Chio SH (1998) Reversible immobilization of chitinase via coupling to reversibly soluble polymer. Enzyme Microb Technol 22:634-640

Wang Y, Xu J, Luo G, Dai Y (2008) Immobilization of lipase by ultrafiltration and cross-linking onto the polysulfone membrane surface. Bioresour Technol. 99:2299-2303

Wei Y, Xu J, Feng Q, Dong H, Lin M (2000) Encapsulation of enzymes in mesoporous host materials via the non surfactanttemplated sol-gel process. Mater Lett 44:6-11

Zarei M, Aminzadeh S, Zolgharnein H, Safahieh A, Daliri M, Noghabi KA, Ghoroghi A, Motallebi A (2011) Characterization of a chitinase with antifungal activity from a native Serratia marcescens B4A. Braz J Microbiol 42:1017-1029 